\title{
Basic and Grade Stress for Some Timber in Sarawak
}

\author{
Gaddafi Ismaili, Badorul Hisham Abu Bakar and Khairul Khuzaimah Abdul Rahim
}

\begin{abstract}
Strength properties' tests are conducted in the small clear sample. This paper aim to acquire the basic and grade stresses of some fast growing species thus identifies its strength group. Thus, the information of wood properties from different species and condition are acquired from strength property's test. The required information namely, bending parallel to the grain, compression stress parallel to grain, shear parallel to grain and modulus of elasticity. The condition of the trees which is referred to green and air-dry condition. Three different species which are referred to exotic species of Acacia mangium and indigenous species of Aras. The results from the study indicated that, Acacia mangium classified under the strength group SG5, whilst Aras was classified under the strength group SG7. The timber is of medium density Light Hardwood ranging from $0.37-0.52 \mathrm{~g} / \mathrm{cm}^{3}$ air-dry condition.
\end{abstract}

Keywords: Bending parallel to the grain, compression stress parallel to grain, shear parallel to grain, modulus of elasticity.

\section{INTRODUCTION}

A lthough the density of timber is relatively reflected the strength of the timber, but it should not be the definite measurement of its strength. It had been understood that timber is homogenous material thus some physical testing had to be conducted to reveal and confirmed the timber strength group as identified from its density. The most suitable sample to be tested that had been suggested by using the small clear sample which is the defect free. [4]. Therefore, the strength properties of some species can be compared and to be concluded by identified its strength group classification on the species that base on Malaysian Standard MS544: Part 2 requirements. The strength group classification on the selected species for this study was subject to the testing results that acquired from compression parallel to grain test, shear parallel to grain test, bending parallel to grain and modulus of elasticity. The strength group classification was conducted in two conditions at green and air-dry. Classification on the strength group on the species was depended on the grade stresses results, i.e. grade select, grade standard and grade common. The strength groups can be classified into seven categories, which base on the strength species namely SG1, SG2, SG3, SG4, SG5, SG6 and SG7.

In timber engineering practice, the ultimate stresses obtained from tests are reduced by applying arbitrary factors [6] to obtain what is called working stresses or permissible stress. These arbitrary reduction factors account for variability of timber duration, and conditions offloading, and factor of safety [4].

\section{EXPERIMENTAL METHODS}

Preparation of specimen

Three timber species namely Acacia mengium and Aras were collected from Sabal Reforestation Plot are used in this study. Sampling of test samples was made throughout the whole length of the tree. The logs were then ripped into half through the pith to obtain the flicthes. The flicthes were planed and machined to 20x20mm for static bending tests. The sticks were visually grade, and only defect free green as well as air-dry samples are cut into specified length and tested. The green condition samples were first to be tested whilst for air-dry condition samples stacked properly for air-drying process. This air-dry process is depending on the type of sample, and this process can be more than nine months. A total of 190 timber samples were used for the bending tests both in each testing condition.

Gaddafi Ismaili was with Reliability Integrity Engineering Department, PETRONAS Carigali Sdn. Bhd., Sarawak Operations, Jalan Sekolah, 98008, Lutong, Miri, Sarawak. He is now with the Faculty of Engineering, Universiti Malaysia Sarawak, Kota Samarahan, 94300 Kota Samarahan, Sarawak, Malaysia (phone: +60 8258 3432; fax: +60 82 583409; e-mail: igaddafi@feng.unimas.my).

Assoc. Prof Dr. Badorul Hisham Abu Bakar is with the School of Civil Engineering, Universiti Sains Malaysia, Engineering Campus, 14300, Nibong Tebal, Seberang Perai, Pulau Pinang, Malaysia (phone: +604 5996298; fax: +604 5941009; e-mail: cebad@eng.usm.my).

Khairul Khuzaimah Abdul Rahim, was with Applied Forest Science and Industry Development Division, Sarawak Forestry Corporation Sdn. Bhd., Lot 218, KCLD Jalan Tapang, Kota Sentosa, 93250 Kuching, Sarawak Malaysia. She is now with the Infrastructure Planning and Development, Protected Areas and Biodiversity Conservation Divison, Sarawak Forestry Corporation Sdn Bhd, Lot 218, KCLD Jalan Tapang, Kota Sentosa, 93250 Kuching, Sarawak Malaysia (phone: +60 8262 9667; fax: +60 8262 9450; e-mail: khairulkr@ sarawakforestry.com) 


\section{Testing methods}

The strength properties' tests are conducted by using destructive test (DT) and results were obtained from two different timber conditions, i.e. green and air-dry conditions. There were four testing results of strength properties were acquired i.e. bending parallel to grain, compression parallel to grain, shear parallel to grain (tangential and radial) and modulus of elasticity. The average shear parallel to grain was from tangential and radial where as the result from the modulus of rupture was referred to the bending parallel to grain. The static bending testing was done in accordance to the British Standard BS 373: 1957 conducted using an Instron Universal Testing Machines with loading capacity of $50 \mathrm{kN}$. A specimen 20 x $20 \mathrm{x}$ $300 \mathrm{~mm}$ in length is supported over a span of $280 \mathrm{~mm}$, and the test is carried out by the three-point bending method. The values of modulus of rupture and modulus of elasticity were electronically calculated by the machine. Compression test results were conducted with $20 \times 20 \times 60 \mathrm{~mm}$ specimen in which special care has been taken to ensure that end-grain surfaces are parallel to each other and normal to the longitudinal axis. The specimen was placed between two compression platen and the rate of upper platen descent $0.6 \mathrm{~mm} / \mathrm{min}$ is used. The property determined is the maximum compression strength parallel to grain. The values of compression stress at maximum load were electronically calculated by the machine.

\section{RESULTS AND DISCUSSION}

\section{Grade stress of Acacia mangium}

Acacia mangium had been known as the most admired planted fast growing species in timber industries. From Table 1, where at green condition, mean results obtained from compression parallel to grain test reveal the basic stress of $17.1 \mathrm{~N} / \mathrm{mm}^{2}$ thus gave the results for grade stresses select, standard, and common were $13.7 \mathrm{~N} / \mathrm{mm}^{2}, 10.8 \mathrm{~N} / \mathrm{mm}^{2}$ and $8.6 \mathrm{~N} / \mathrm{mm}^{2}$ respectively. From the result, it has been classified under SG4. Where by the average mean results from shear parallel to grain test reveal that the basic stress value is $3.0 \mathrm{~N} / \mathrm{mm}^{2}$ and thus contributed the grade stresses for select, standard, and common with $2.4 \mathrm{~N} / \mathrm{mm}^{2}, 1.9 \mathrm{~N} / \mathrm{mm}^{2}$, and $1.5 \mathrm{~N} / \mathrm{mm}^{2}$ respectively. Thus, this has been classified under SG1. Basic stress for MOR or bending parallel to grain is $24.4 \mathrm{~N} / \mathrm{mm}^{2}$ and thus concluded that the grade stresses of select, standard, and common are $19.5 \mathrm{~N} / \mathrm{mm}^{2}, 15.3 \mathrm{~N} / \mathrm{mm}^{2}$, and $12.2 \mathrm{~N} / \mathrm{mm}^{2}$ respectively. This has been classified under SG2. Whilst, for modulus of elasticity, the grade stresses is $6044 \mathrm{~N} / \mathrm{mm}^{2}$ and identified under SG5. As recommended by Malaysian Standard MS544: Part 2, this can be concluded that strength group for Acacia mangium is classified under SG5 as it is the lowest case between strength groups that had been obtained from different tests at green condition.

At the air-dry condition, it is revealed that the basic stress value of compression parallel to grain is recorded $17.3 \mathrm{~N} / \mathrm{mm}^{2}$. These gave the grade stresses results for select, standard, and common with $13.8 \mathrm{~N} / \mathrm{mm}^{2}, 10.9 \mathrm{~N} / \mathrm{mm}^{2}$ and $8.6 \mathrm{~N} / \mathrm{mm}^{2}$ respectively. Therefore, it has been classified under SG4. Meanwhile, the average mean result of basic stress for shear parallel to grain is given $3.2 \mathrm{~N} / \mathrm{mm}^{2}$ with the grade stresses of select, standard, and common are $2.5 \mathrm{~N} / \mathrm{mm}^{2}, 2.0 \mathrm{~N} / \mathrm{mm}^{2}$, and $1.6 \mathrm{~N} / \mathrm{mm}^{2}$ respectively thus classified under SG2. Basic stress for bending parallel to grain is $25.5 \mathrm{~N} / \mathrm{mm}^{2}$ thus contributed the results for grade stresses select, standard, and common with $20.4 \mathrm{~N} / \mathrm{mm}^{2}, 16.1 \mathrm{~N} / \mathrm{mm}^{2}$ and $12.7 \mathrm{~N} / \mathrm{mm}^{2}$ respectively thus fall under SG3. Whilst, for modulus of elasticity, the grade stresses is $7586 \mathrm{~N} / \mathrm{mm}^{2}$ and classified under SG4. This can be concluded that strength group of Acacia mangium at the air-dry condition is classified under SG4. Thus for overall conclusion, Acacia mangium species is prone to be classified under SG5 as it is the lowest case between the strength group at the green and air-dry condition.

\section{Grade stress of Aras}

Aras at green condition reported with the mean compression parallel to grain is $8.3 \mathrm{~N} / \mathrm{mm}^{2}$. This result has contributed the grade stresses for select, standard, and common with $6.6 \mathrm{~N} / \mathrm{mm}^{2}, 5.2 \mathrm{~N} / \mathrm{mm}^{2}$, and $4.1 \mathrm{~N} / \mathrm{mm}^{2}$ respectively as shown clearly in Table 1. Consequently, from this result, Aras had been classified under the strength group SG6. The average mean shear parallel to grain has reported contributed the results for grade stresses select, standard, and common with $1.4 \mathrm{~N} / \mathrm{mm}^{2}$, $1.1 \mathrm{~N} / \mathrm{mm}^{2}$, and $0.9 \mathrm{~N} / \mathrm{mm}^{2}$ respectively. This gave shear parallel to grain test is classified under SG4. Aras's basic stress for bending parallel to grain is $10.2 \mathrm{~N} / \mathrm{mm}^{2}$ which has contributed the grade stresses of select, standard, and common values with $8.2 \mathrm{~N} / \mathrm{mm}^{2}, 6.4 \mathrm{~N} / \mathrm{mm}^{2}$, and $5.1 \mathrm{~N} / \mathrm{mm}^{2}$. From the result, it is classified under SG6, which is much lower compared to Acacia mangium with SG2. Furthermore, for modulus of elasticity, the grade stresses is $3491 \mathrm{~N} / \mathrm{mm}^{2}$ and classified under SG7. This can be concluded that, at green condition, Aras is classified under SG7 compared to Acacia mangium with SG5 as it is the lowest case between strength groups that had been obtained from different tests.

Aras at the air-dry condition has revealed that basic stress for compression parallel to grain with $14.7 \mathrm{~N} / \mathrm{mm}^{2}$. This has contributed the result for grade stresses select, standard, and common with $11.7 \mathrm{~N} / \mathrm{mm}^{2}, 9.2 \mathrm{~N} / \mathrm{mm}^{2}$ and $7.3 \mathrm{~N} / \mathrm{mm}^{2}$ thus 
classified under SG5, which is relatively close to Acacia mangium with SG4. The average basic stress for shear parallel to grain is $2.9 \mathrm{~N} / \mathrm{mm}^{2}$ with the grade stresses of select, standard, and common are $2.3 \mathrm{~N} / \mathrm{mm}^{2}, 1.8 \mathrm{~N} / \mathrm{mm}^{2}, \mathrm{and} 1.4 \mathrm{~N} / \mathrm{mm}^{2}$ respectively. Thus from the result it is classified under SG2, which is relatively similar with Acacia mangium. The basic stress for modulus of elasticity is $16.3 \mathrm{~N} / \mathrm{mm}^{2}$. This has given the grade stresses select, standard, and common with $13.0 \mathrm{~N} / \mathrm{mm}^{2} 10.2 \mathrm{~N} / \mathrm{mm}^{2}$ and $8.1 \mathrm{~N} / \mathrm{mm}^{2}$ respectively. Therefore from the results it can be classified under SG5. Moreover, for modulus of elasticity, the grade stresses is $5507 \mathrm{~N} / \mathrm{mm}^{2}$ and it is classified under SG6. The strength group obtained for each test at the air-dry condition thus can be concluded fall under SG6 compared to Acacia mangium which is classified under SG4 as it is the lowest case between strength groups. From both conditions, green and air-dry, it is to be concluded that Aras's strength group is prone to be classified under SG7, and it is lower compared to Acacia mangium with SG5.

\begin{tabular}{|c|c|c|c|c|c|c|c|c|c|c|c|c|c|c|c|c|}
\hline \multirow{2}{*}{$\begin{array}{l}\frac{\infty}{0} \\
\frac{0}{2} \\
\tilde{2}\end{array}$} & \multirow{2}{*}{ 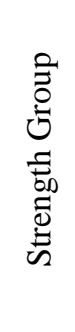 } & \multirow{2}{*}{ نี } & \multicolumn{4}{|c|}{$\begin{array}{l}\text { Bending Parallel to the Grain } \\
\qquad\left(\mathrm{N} / \mathrm{mm}^{2}\right)\end{array}$} & \multicolumn{4}{|c|}{$\begin{array}{l}\text { Compression Parallel to the } \\
\text { Grain } \\
\left(\mathrm{N} / \mathrm{mm}^{2}\right)\end{array}$} & \multicolumn{4}{|c|}{$\begin{array}{l}\text { Shear Parallel to the } \\
\text { Grain } \\
\left(\mathrm{N} / \mathrm{mm}^{2}\right)\end{array}$} & \multicolumn{2}{|c|}{$\begin{array}{l}\text { Modulus of } \\
\text { Elasticity } \\
\left(\mathrm{N} / \mathrm{mm}^{2}\right)\end{array}$} \\
\hline & & & $\cdot \frac{0}{\tilde{m}}$ & $\frac{\vec{U}}{\frac{\ddot{d}}{\omega}}$ & 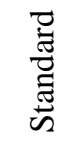 & ¿ే & $\cdot \frac{0}{\sqrt[n]{5}}$ & $\begin{array}{l}\frac{\vec{U}}{\Delta} \\
\stackrel{\Delta}{D}\end{array}$ & 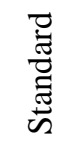 & 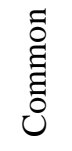 & $\frac{\cdot}{\tilde{E}}$ & $\frac{\vec{U}}{\frac{U}{D}}$ & 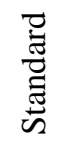 & ఏ̊̃ & 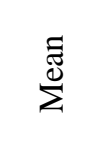 & $\stackrel{\Xi}{\Xi}$ \\
\hline \multirow{2}{*}{$\begin{array}{l}\text { Acacia } \\
\text { mangium }\end{array}$} & \multirow{2}{*}{ SG5 } & Green & 24.4 & 19.5 & 15.3 & 12.2 & 17.1 & 13.7 & 10.8 & 8.6 & 3.0 & 2.4 & 1.9 & 1.5 & 11421 & 6044 \\
\hline & & Dry & 25.5 & 20.4 & 16.1 & 12.7 & 17.3 & 13.8 & 10.9 & 8.6 & 3.2 & 2.5 & 2.0 & 1.6 & 12065 & 7586 \\
\hline \multirow{2}{*}{ Terbulan } & \multirow{2}{*}{ SG7 } & Green & 11.6 & 9.3 & 7.3 & 5.8 & 7.4 & 5.9 & 4.7 & 3.7 & 1.4 & 1.2 & 0.9 & 0.7 & 8022 & 4860 \\
\hline & & Dry & 17.6 & 14.1 & 11.1 & 8.8 & 13.7 & 11.0 & 8.6 & 6.8 & 2.6 & 2.1 & 1.6 & 1.3 & 8911 & 5532 \\
\hline \multirow{2}{*}{ Aras } & \multirow{2}{*}{ SG7 } & Green & 10.2 & 8.2 & 6.4 & 5.1 & 8.3 & 6.6 & 5.2 & 4.1 & 1.8 & 1.4 & 1.1 & 0.9 & 6360 & 3491 \\
\hline & & Dry & 16.3 & 13.0 & 10.3 & 8.1 & 14.7 & 11.7 & 9.2 & 7.3 & 2.9 & 2.3 & 1.8 & 1.4 & 8214 & 5507 \\
\hline
\end{tabular}

Table 1 Green and dry grade stresses and modulus of elasticity.

\section{CONCLUSION}

The basic and grade stresses for strength groups can be used to facilitate the design, stocking and supply of timber for structural purposes [3]. The species was recommended mainly for general utility for furniture making and other nonstructural applications. For structural design purposes, the results from small clear must not be used directly it must be first derived into permissible stresses. Thus appropriate modification factors had to be identified as given British Standard CP 112:1967 or Malaysian Standard MS544: Part 2 should be used. It was found that, exotic species of Acacia mangium was obviously known under SG5 and has been also proven in this study. Indigenous species of Aras has been classified under the strength group SG7. It is found that the strength properties' values for bending parallel to the grain, compressive stress parallel to the grain, shear parallel to the grain and modulus of elasticity for Acacia mangium are $92.31 \mathrm{~N} / \mathrm{mm}^{2}, 39.49 \mathrm{~N} / \mathrm{mm}^{2}$, $5.215 \mathrm{~N} / \mathrm{mm}^{2}$ and $11742.79 \mathrm{~N} / \mathrm{mm}^{2}$ respectively. As for Aras, it is revealed that with $58.93 \mathrm{~N} / \mathrm{mm}^{2}, 28.28 \mathrm{~N} / \mathrm{mm}^{2}, 8.76 \mathrm{~N} / \mathrm{mm}^{2}$ and $7286.85 \mathrm{~N} / \mathrm{mm}^{2}$ respectively.

\section{ACKNOWLEDGMENT}

The authors wish to gratefully acknowledge all staffs of Mechanical Testing Section, especially to Research Manager Dr. Alik Duju for their assistance and support for this research.

\section{REFERENCES}

[1] British Standard (1957). Methods of Testing Small Clear Specimen of Timber. British Standard Institution. BS 373: 1957. 31pp.

[2] British Standard Code of Practice CP 112:1967. British Standards Institute, London.

[3] Engku Abdul Rahman Bin Chik (1978). Basic and Grade Stresses for Strength Groups of Malaysian Timbers, Malaysian Forest Service Trade Leaflet No. 38, Kuala Lumpur, Malaysia.

[4] Engku Abdul Rahman Bin Chik (1988). Basic and Grade Stresses for some Malaysian Timbers, Timber Trade Leaflet No. 37, Kuala Lumpur, Malaysia. 
UNIMAS E-Journal of Civil Engineering, Vol. 2 (2) 2011

[5] Malaysian Standard (2001). Malaysian Standard MS544: Part 2. Code of Practice on Structural use of timber (First revision). Department of Standards Malaysia.

[6] Thomas, A.V. (1948). Allowable Working stresses for Malayan Timbers Trade Leaflet No.7. Forest Department, Kuala Lumpur. 